\title{
The $\mathrm{nM}$ ouabain-induced tissue dehydration as a novel diagnostic marker for neuronal pathology
}

\author{
Sinerik Ayrapetyan* \\ UNESCO Chair-Life Sciences International Postgraduate Educational Center, Yerevan, Armenia
}

Cell hydration is a dynamic parameter determining its functional activity which is realized by hydration-induced changes of intracellular macromolecules' activity by folding-unfolding mechanism [1] and by surface-dependent changes of a number of functionally active membrane proteins, having enzymes [2], receptors [3] and ionic channels forming properties [4]. As membrane is highly permeable for water and intracellular osmotic pressure exceeds the extracellular one, it is assumed that there is a metabolically driven water efflux from the cell in order to balance osmotic water uptake. Previously we have shown that water influx increases membrane permeability for $\mathrm{Na}^{+}\left(\mathrm{P}_{\mathrm{Na}}\right)$, while water efflux from the cell has opposite effect on it [4] Therefore, water influx as a result of metabolic water efflux impairment increases $\mathrm{P}_{\mathrm{Na}}$, which in its turn decreases $\mathrm{Na}^{+}$gradient on membrane being a common consequence of any cell pathology. Therefore, it is suggested that the impairment of metabolically driven water efflux, which compensates the osmotically driven water uptake by cell leading to the increase of membrane permeability for $\mathrm{P}_{\mathrm{Na}}$, can be considered as a primary gate for generation of cell pathology [5].

It is known that metabolic water efflux is due to membrane ion transporting mechanisms that work in electrogenic regime, such as $\mathrm{Na}^{+} / \mathrm{K}^{+}$pump (stoichiometry of $3 \mathrm{Na}^{+}: 2 \mathrm{~K}^{+}$) and $\mathrm{Na}^{+} / \mathrm{Ca}^{2+}$ exchange in reverse mode ( $\mathrm{R}$ ) (stoichiometry of $3 \mathrm{Na}^{+}: 1 \mathrm{Ca}^{2+}$ ). During the function of these mechanisms cell loses more osmotic particles than accumulates them.

The next mechanism that generates water efflux from the cell is oxidative phosphorylation-induced release of water molecules in cytoplasm [6].

It has been shown that there is a negative close correlation between $\mathrm{Na}^{+} / \mathrm{K}^{+}$pump and $\mathrm{Na}^{+} / \mathrm{Ca}^{2+}$ exchange and the latter is more sensitive to metabolic factors, such as intracellular messengers [7]. However, the detailed mechanism of the role of intracellular messengers in regulation of $\mathrm{Na}^{+} / \mathrm{Ca}^{2+}$ exchange has not been fully elucidated.

It is known that in neuronal and muscle membranes $\mathrm{Na}^{+} / \mathrm{K}^{+}$ATPase (working molecules of $\mathrm{Na}^{+} / \mathrm{K}^{+}$pump) has three catalytic isoforms $\left(\alpha_{1}, \alpha_{2}, \alpha_{3}\right)$ [8] with different affinities to cardiac glycoside ouabain and functional activities: $\alpha_{1}$ (with low affinity) and $\alpha_{2}$ (with middle affinity) isoforms are involved in transportation of $\mathrm{Na}^{+}$and $\mathrm{K}^{+}$, while $\alpha_{3}$ (with high affinity) isn't directly involved in transporting $\mathrm{Na}^{+}$and $\mathrm{K}^{+}$and has only intracellular signaling function $[8,9]$ through which $\mathrm{Na}^{+} / \mathrm{Ca}^{2+}$ exchange is regulated.

The study of dose-dependent effect of ouabain on $\mathrm{Na}^{+}$efflux from perfused axon has shown that $\mathrm{Na}^{+}$efflux from the cell has ouabain sensitive and ouabain insensitive components. It has been shown that ouabain sensitive component is determined by $\mathrm{Na}^{+} / \mathrm{K}^{+}$pump, while ouabain insensitive component is determined by $\mathrm{R} \mathrm{Na}^{+} / \mathrm{Ca}^{2+}$ exchange $[7,8]$.

Our study performed on intact neurons has shown that extremely low concentrations $\left(<10^{-9} \mathrm{M}\right)$ of ouabain stimulate $\mathrm{Na}^{+}$efflux from the cell without inhibiting $\mathrm{Na}^{+} / \mathrm{K}^{+}$pump. From this data, it has been concluded that there is an unknown intracellular mechanism responsible for $\mathrm{Na}^{+}$efflux from the cell which is not due to $\mathrm{Na}^{+} / \mathrm{K}^{+}$ pump activity [2]. Later it has been shown that low concentrations of ouabain which are unable to inactivate $\mathrm{Na}^{+} / \mathrm{K}^{+}$pump, stimulate $\mathrm{Na}^{+} /$ $\mathrm{Ca}^{2+}$ exchange which is accompanied by the increase of intracellular cAMP content [10]. Further studies have revealed that nM ouabain has stimulation effect on cAMP content in different cells [11]. However, after discovering the existence of cAMP-activated $\mathrm{Ca}^{2+}$ pump in the membrane of endoplasmic reticulum (ER) which pushes $\mathrm{Ca}^{2+}$ from cytoplasm into endoplasm [12] it became clear that cAMP-induced activation of $\mathrm{R} \mathrm{Na}^{+} / \mathrm{Ca}^{2+}$ exchange is due to the decrease of intracellular $\mathrm{Ca}^{2+}$ as a result of stimulation of cAMP-activated $\mathrm{Ca}^{2+}$ pump in ER [11].

As $\mathrm{Na}^{+} / \mathrm{Ca}^{2+}$ exchanger works in stoichiometry of $3 \mathrm{Na}^{+}: 1 \mathrm{Ca}^{2+}$, it was predicted that $\mathrm{R} \mathrm{Na}^{+} / \mathrm{Ca}^{2+}$ exchange should have dehydration effect on cell, while $\mathrm{F} \mathrm{Na}^{+} / \mathrm{Ca}^{2+}$ exchange hydration effect on it. However, our recent study has shown that $\mathrm{nM}$ ouabain-induced activation of $\mathrm{R} \mathrm{Na}^{+} /$ $\mathrm{Ca}^{2+}$ exchange leads to cell hydration (instead of cell dehydration) in brain tissues of young animals, while in old animals it has dehydration effect on it. Moreover, this nM ouabain-induced dehydration effect in old animals is also observed in vitro experiments, where metabolic activity of cell is in depressed state [13]. The more detailed investigation has revealed that this age-dependent difference of nM ouabain effect on cell hydration is due to the initial metabolic state of organism. In young animals, the nM ouabain-induced activation of cAMP leads to endogenous water release as a result of activation of oxidative phosphorylation processes in cell, while in old animals the cAMPdependent activation of intracellular oxidative phosphorylation is depressed as a result of abnormal increase of intracellular $\mathrm{Ca}^{2+}$ content inhibiting mitochondrial function. From these data, we have concluded that during cell pathology (including aging) the increase of intracellular $\mathrm{Ca}^{2+}$ brings to the dysfunction of mitochondria (depresses oxidative phosphorylation-induced release of $\mathrm{H}_{2} \mathrm{O}$ ).

Thus, on the basis of the above-mentioned data we suggest that nM

Correspondence to: Sinerik Ayrapetyan, UNESCO Chair-Life Sciences International Postgraduate Educational Center, Yerevan, Armenia 31 Acharyan St. 0040 Yerevan, Armenia, E-mail: info@biophys.am

Received: November 21, 2016; Accepted: December 15, 2016; Published: December 19, 2016 
ouabain-induced dehydration can be considered as a novel diagnostic marker and therapeutic target.

\section{References}

1. Parsegian VA, Rand RP, Rau DC (2000) Osmotic stress, crowding, preferential hydration, and binding: A comparison of perspectives. Proc Natl Acad Sci U S A 97: 3987-3992. [Crossref]

2. Ayrapetyan SN, Suleymanyan MA, Saghyan AA, Dadalyan SS (1984) Autoregulation of the electrogenic sodium pump. Cell Mol Neurobiol 4: 367-383. [Crossref]

3. Ayrapetyan SN, Arvanov VL, Maginyan SB, Azatyan KV (1985) Further study of the correlation between Na-pump activity and membrane chemosensitivity. Cell Mol Neurobiol 5: 231-243. [Crossref]

4. Ayrapetyan SN, Rychkov GY, Suleymanyan MA (1988) Effects of water flow on transmembrane ionic currents in neurons of Helix pomatia and in squid giant axons. Comp Biochem Physiol A Comp Physiol 89: 179-186. [Crossref]

5. Ayrapetyan SN (2016) Cell hydration-induced changes of membrane conductivity as a marker for estimation of biological effects of chemical and physical factors on organism. J Bioequiv Availab 8:10000e72.
6. Lehninger AL (1970) Mitochondria and calcium ion transport. Biochem J 119: 129138. [Crossref]

7. Baker PF, Blaustein MP, Hodgkin AL, Steinhardt RA (1969) The influence of calcium on sodium efflux in squid axons. $J$ Physiol 200: 431-458. [Crossref]

8. Blaustein MP, Lederer WJ (1999) Sodium/calcium exchange: its physiologica implications. Physiol Rev 79: 763-854. [Crossref]

9. Xie Z, Askari A (2002) $\mathrm{Na}(+) / \mathrm{K}(+)$-ATPase as a signal transducer. Eur J Biochem 269: 2434-2439. [Crossref]

10. Saghian AA, Ayrapetyan SN, Carpenter DO (1996) Low concentrations of ouabain stimulate $\mathrm{Na} / \mathrm{Ca}$ exchange in neurons. Cell Mol Neurobiol 16: 489-498. [Crossref]

11. Narinyan L, De J, Ayrapetyan S (2014) Age-dependenti in $\mathrm{Ca}^{2+}$ exchange magnetosensitivity in rat heart muscles. Biochemistry and Biophysics 2: 1-3

12. Brini M, Carafoli E (2009) Calcium pumps in health and disease. Physiol Rev 89: 13411378. [Crossref]

13. Heqimyan A, Narinyan L, Nikoghosyan A, Ayrapetyan S (2015) Age-dependent magnetic sensitivity of brain and heart muscles, In: M. Markov (Ed.) Electromagnetic Fields in Biology and Medicine, USA, CRC Press, pp. 217-230.

Copyright: (2016 Ayrapetyan A. This is an open-access article distributed under the terms of the Creative Commons Attribution License, which permits unrestricted use, distribution, and reproduction in any medium, provided the original author and source are credited. 